\title{
ОТ ПЕРЕГОВОРНОЙ КАБИНЫ до первого советского таксофона
}

\author{
О.Фролова, заведующая информационно-методическим \\ отделом Центрального музея связи \\ имени А.С.Попова / o.fro67@mail.ru
}

УДК 621.395.361, DOI: 10.22184/2070-8963.2019.83.6.74.79

Представлен очерк истории отечественных таксофонов от "телефонов общественного пользования" до телефонов-автоматов серии "В".

Еще совсем недавно телефон-автомат был важной частью нашей повседневной жизни. Массовое применение таксофонов ушло в прошлое, однако они остаются важным этапом развития телефонной техники.

Слово "таксофон" произошло от лат. taxare - оценивать и phone - звук, голос. Другое общепринятое название таксофона - телефон-автомат. Таксофон - это автоматический телефонный аппарат, в котором соединение с вызываемым абонентом происходит после опускания монеты или специального жетона. Кроме передачи речи, таксофоны выполняют функции оплаты разговора, контроля времени и средств оплаты.

Предшественниками первых телефонов-автоматов стали "телефоны общественного пользования" - общедоступные телефонные аппараты, которые устанавливали в общественных местах (в ресторанах, на вокзалах, в фойе театров и т.д.). Плату за пользование ими принимал специальный служащий, кассир-контролер. Первые сведения о предоставлении такой услуги относятся к 1881 году. Вскоре после организации телефонной сети в Берлине, там был установлен телефонный аппарат для общего пользования с оплатой 50 пфеннигов за 5 мин разговора [3].

Широко известна история о том, как в 1889 году американец Уильям Грей, пытаясь вызвать врача к больной жене, потратил много сил и времени на уговоры владельца одного из немногочисленных телефонных аппаратов, чтобы тот разрешил сделать необходимый звонок. После этого Грей поставил перед собой цель - создать телефон, который выполнял бы функции кассира. Вскоре, в 1890 году, в американском городе Хартфорде был установлен первый общественный телефонавтомат. В том же году он был продемонстрирован на Всемирной выставке в Париже. В 1891 году У.Грей учредил собственную телефонную компанию по производству телефонов-автоматов. Есть также информация о том, что первый образец таксофона был представлен тогда же на международной электротехнической выставке во Франкфурте (Германия) [3].

В том же 1891 году российский журнал "Электричество" сообщал об изобретении "автоматического кассира для общественных телефонных станций". Американский изобретатель Говард Руперт создал прибор, уведомлявший телефониста на центральной станции об опущенной монете. Кассир, услышав сигнал, мог контролировать время разговора. Автор статьи отмечал, что на тот момент уже было изобретено несколько подобных автоматических устройств, но прибор Руперта отличается простотой и надежностью, и "его не трудно было бы приспособить для русских серебряных монет". K тому времени общественные телефонные 
станции, доказавшие свою полезность и практичность, "уже устроены во многих городах Америки и западной Европы", и автор выражал пожелание, чтобы "это полезное учреждение" поскорее привилось и в России [4].

Таким образом, к началу 1890-х годов в разных странах шла активная работа по созданию эффективного и надежного автоматического устройства, позволявшего оплачивать переговоры по телефону и контролировать их время. До внедрения автоматической телефонной связи, в эпоху ручных коммутаторов, телефонные аппараты для разовых оплаченных переговоров имели встроенный или отдельно подключаемый прибор, который включал монетоприемник ("копилку") и электромеханическое устройство, подававшее звуковой сигнал телефонистке на станции, что оплата произведена.

Однако внедрение новинки - телефонов-автоматов - происходило не очень быстро. Постепенно они появлялись на городских телефонных сетях. Даже в Германии, активно внедрявшей новинки телефонной техники, первые таксофоны для местной связи были установлены только в 1899 году в почтовых конторах Берлина, стоил разговор 10 пфеннигов. Вскоре появились междугородные таксофоны на линии Берлин - Мюнхен, разговор по которым стоил дороже [3].

Первые сведения о "телефонах общественного пользования" в Российской империи относятся к началу 1890-х годов. В обзоре развития Киевской телефонной сети за первые пять лет работы (18861891) заведующий сетью П.Барабанов писал, что в Киеве "для удобства публики... устроены особые говорильные будки". Всего их было пять в разных частях города, пятиминутный разговор стоил 25 коп. К сожалению, не указано, какая система оплаты использовалась: с помощью автоматического устройства или при помощи кассира-контролера. Доходность "говорильных будок" была невысокой - до 30 руб. в год, а среднее число разговоров - один в два дня [2]. Как видно, в то время "общественные телефоны" не пользовались большой популярностью, что, в общем-то, неудивительно - абонентов на телефонных сетях было немного в силу высокой платы за подключение и пользование телефоном.

Переговорные пункты с "общественными телефонами" были созданы и в обеих столицах - Санкт-Петербурге и Москве, телефонные сети которых по концессии построила и эксплуатировала Международная компания телефонов Белла. Их было немного, и действовали они при центральных телефонных станциях и в нескольких других пунктах.

В 1893 году была сделана первая попытка широкого внедрения "телефонов общественного пользования" в Москве и Санкт-Петербурге. Инженер И.В.Попов предложил создать сеть "телефонных киосков", где разовые телефонные переговоры предоставлялись бы всем желающим. Московская городская дума отказалась отвести участки для постройки киосков, и дело встало. Однако Попов не оставил свою идею, и в 1899 году император Николай II утвердил "Правила устройства комиссионных павильонов с телефонным сообщением". Предполагалось, что при этих павильонах, устроенных в людных местах, помимо предоставления телефонных переговоров, особые служащие будут выполнять поручения - передавать телефонограммы (переданные по телефону и записанные сообщения), звать нужное лицо к телефону, наводить и выдавать справки и т. д. Однако дело затянулось, и в 1905 году в Москве Попов вновь получил отказ [5].

Неугомонный инженер в 1910 году вновь обратился за разрешением на концессию на открытие до 14-ти "справочных павильонов" в СанктПетербурге. Он планировал устроить их на вокзалах и в других подходящих местах (суд, адресный стол). Там, помимо предоставления возможности позвонить абоненту, также должны были выдавать справки по телефону. Эти павильоны были приравнены к ранее разрешенным "комиссионным павильонам с телефонным сообщением". Одновременно Попов заключил соглашение с судебными органами об открытии специальной "переговорной станции", пытался договориться с городской управой и другими учреждениями. Однако в Петербурге, в том числе на вокзалах, уже работали "переговорные павильоны" Восточно-Финляндского телефонного общества, эксплуатировавшего линию Петербург - Териоки (ныне - Зеленогорск). Концессия этой компании должна была вскоре закончиться, но ей покровительствовал инспектор Главного управления почт и телеграфов Л.Корнатовский. Попов подал протест с жалобой на Корнатовского и в конце концов получил разрешение на открытие десяти переговорных пунктов [5]. О том, что было дальше, архивные документы умалчивают, нет и сведений об открытии в столице сети "телефонных киосков" Попова. Таким образом, это начинание потерпело неудачу, и оба города лишись возможности расширить количество людей, пользовавшихся телефонной 


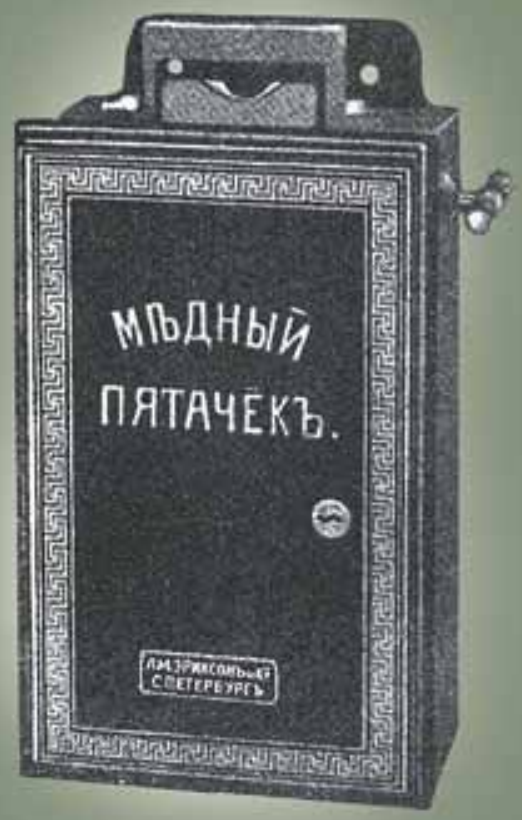

Рис.1. Телефонный автомат ("копилка") "Медный пятачок". Из книги "Твой телефон, Москва. 120 лет Московской городской телефонной сети"

связью. Вполне возможно, что "телефонные киоски" Попова воспринимались как конкуренция постепенно внедрявшимся на городских сетях телефонам-автоматам.

В настоящее время считается, что первый отечественный телефон-автомат (так тогда назвали таксофоны) был установлен в почтово-телеграфной конторе в Ораниенбауме в 1903 году. Заметку об этом опубликовала газета "Русский листок". Однако видный русский инженер и изобретатель Владислав Нагорский (впоследствии начальник Санкт-Петербургского почтово-телеграфного округа) в своей автобиографии писал, что занимался внедрением телефонов-автоматов в Петербурге немного раньше - в 1901 году [1]. Пока не удалось найти сведения об этой его работе, но в журнале "Записки Императорского Русского технического общества" в обзоре привилегий (патентов) за 1901 год описывается привилегия на телефон-автомат, выданная иностранным подданным И.Вратичу и Ст.Гергачевичу. В этом устройстве использовалась специальная

"металлическая марка" (жетон), которая отпирала телефонный киоск и одновременно служила средством оплаты [6]. Нет сведений о внедрении этого изобретения, однако идея об оплате телефонных переговоров не только монетами позже получила развитие.

С 1903 года в нашей стране начали применяться телефонные автоматы системы Эрикссона. Телефонная фабрика Русского акционерного общества "Л.М.Эриксон и Ко" выпускала три типа устройств для разовых платных телефонных переговоров. Два из них - приборы, которые являлись дополнением к обыкновенному телефонному аппарату. Телефонный автомат "Медный пятачок" (рис.1) имел прерыватель тока для сигнала об оплате, был снабжен счетчиком числа разговоров и предназначался только для медных пятикопеечных монет. Более дешевый прибор из чугуна имел вибрирующую пластинку для сигнала об оплате и предназначался для монет достоинством 5, 10 и 15 коп. [7].

Более удобен и технически совершенен был настенный телефонный аппарат, скомбинированный с автоматом для оплаты. Он предназначался для серебряных монет в 10 и 15 коп. Центральную станцию можно было вызвать только после опускания монеты. Потом надо было нажать кнопку справа - монета опускалась в копилку, замыкала вибрирующую пластинку, дававшую телефонистке сигнал, что оплата произведена. Если линия была занята, то монета освобождалась при помощи специальной кнопки слева. Монеты меньшего размера автоматически выбрасывались из копилки. При заказе аппарата необходимо было указать, на какой номинал необходимо его настроить [7], - каждая телефонная сеть имела свои тарифы на разговоры по "общественному телефону".

Вопреки общепринятому мнению телефоныавтоматы были достаточно распространены в Российской империи, и не только в столицах. В сельской местности телефоны-автоматы использовались на земских уездных телефонных сетях. Также их устанавливали на немногочисленных междугородных линиях. Они были востребованы, поскольку позволяли обходиться без дополнительного обслуживающего персонала. Но уже в то время стояла проблема мошенничества при оплате переговоров - в автоматы опускали посторонние предметы, близкие к монетам по форме и весу, использовали продырявленные монеты на веревочке, которые вытаскивали по окончании разговора, и другие способы. 


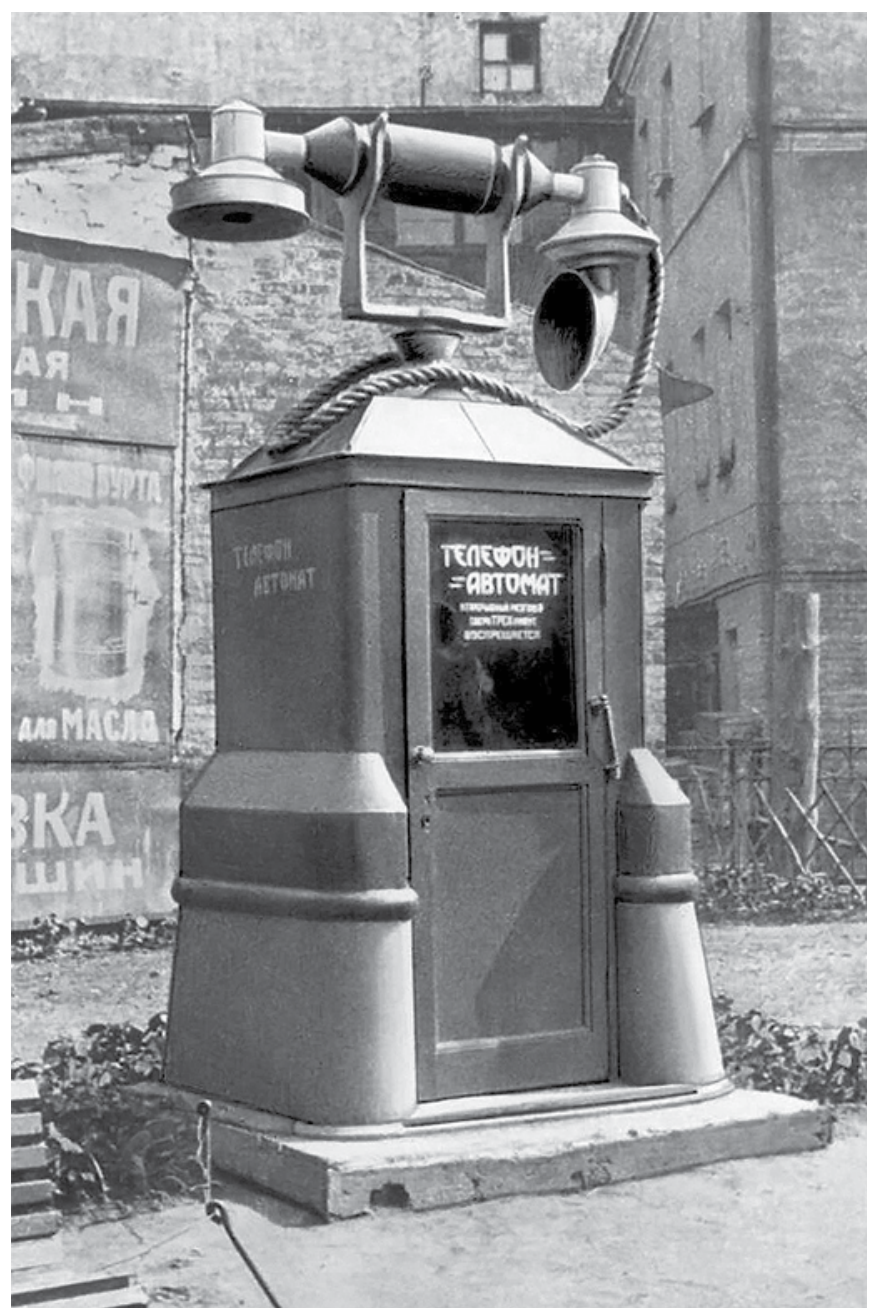

Рис.2. Кабина телефона-автомата. Москва. 1920-е годы

Телефоны-автоматы (их еще называли публичными телефонами) обычно устанавливались в людных общественных местах, в первую очередь там, где имелась повышенная потребность в оперативной связи - в театрах и ресторанах, на бирже, на вокзалах и т. п. Для звукоизоляции и удобства пользователей строились специальные телефонные будки. Их эволюция шла параллельно эволюции таксофонов. На первом этапе это были массивные деревянные сооружения, но в дальнейшем дизайн и устройство телефонных кабин весьма варьировались, приспосабливаясь к городской среде.

После революционных событий 1917 года все отечественные телефонные сети были национализированы. Гражданская война нанесла им огромный урон. В период экономической разрухи был издан декрет от 6 мая 1920 года, который предписывал конфисковать и передать государству

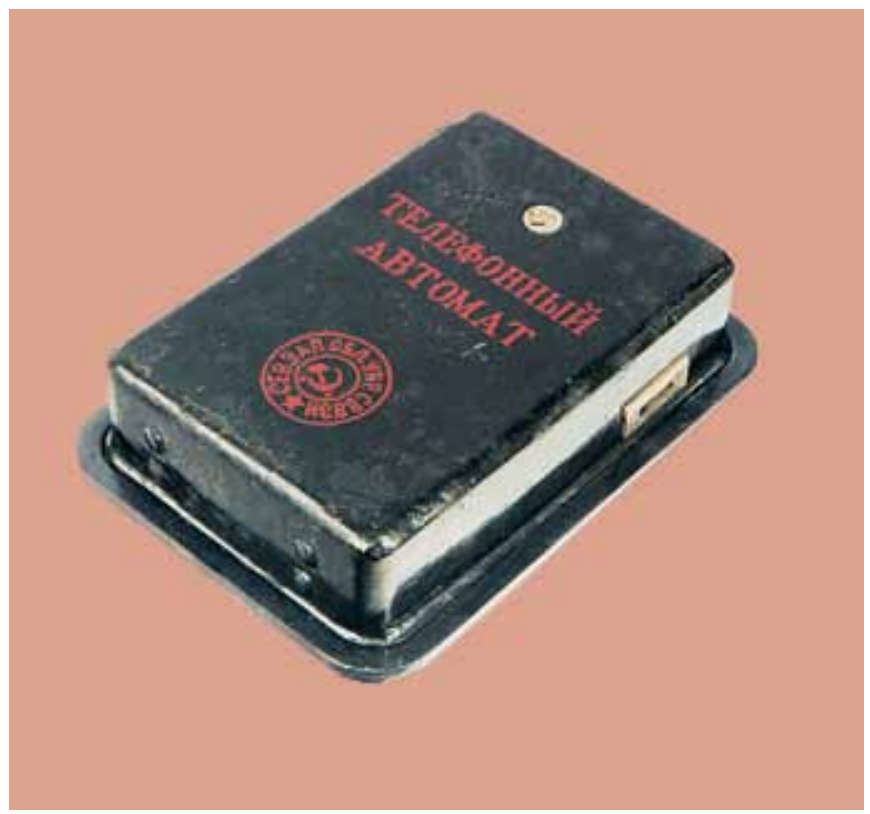

Рис.3. Телефонный автомат ("копилка"). СССР. 1920-е годы. Из фондов ЦМС имени А.С.Попова

большую часть телефонных аппаратов, находившихся в личном пользовании граждан, для установки в учреждениях. Одновременно было указано увеличить количество бесплатных телефонов общественного пользования, однако это не было выполнено. В 1921 году в Москве действовало 10 телефонов-автоматов, которые для сохранности устанавливались в учреждениях.

После отказа от политики военного коммунизма и перехода к НЭПу (новой экономической политике) услуги телефонной связи стали платными. Однако все осложнялось не только отсутствием телефонных аппаратов и запасных частей к ним, но и денежной инфляцией. В 1924 году, после денежной реформы и введения серебряной монеты, в Москве было около 100 таксофонов, началась установка телефонных кабин на московских улицах (рис.2) [9]. В том же году появились телефоны-автоматы и в Ленинграде, выросло число переговорных пунктов [8]. Не отставала и провинция - журнал "Жизнь и техника связи" в 1920-е годы регулярно рассказывал о внедрении телефонов-автоматов в стране, особенно выделяя Закавказье, прежде всего Баку.

В то время в качестве таксофонов по-прежнему использовали обычные телефонные аппараты, снабженные специальным устройством с приставкой-копилкой для монет одного определенного достоинства (рис.3). Телефоны-автоматы конструкции Эрикссона выпускались и после 


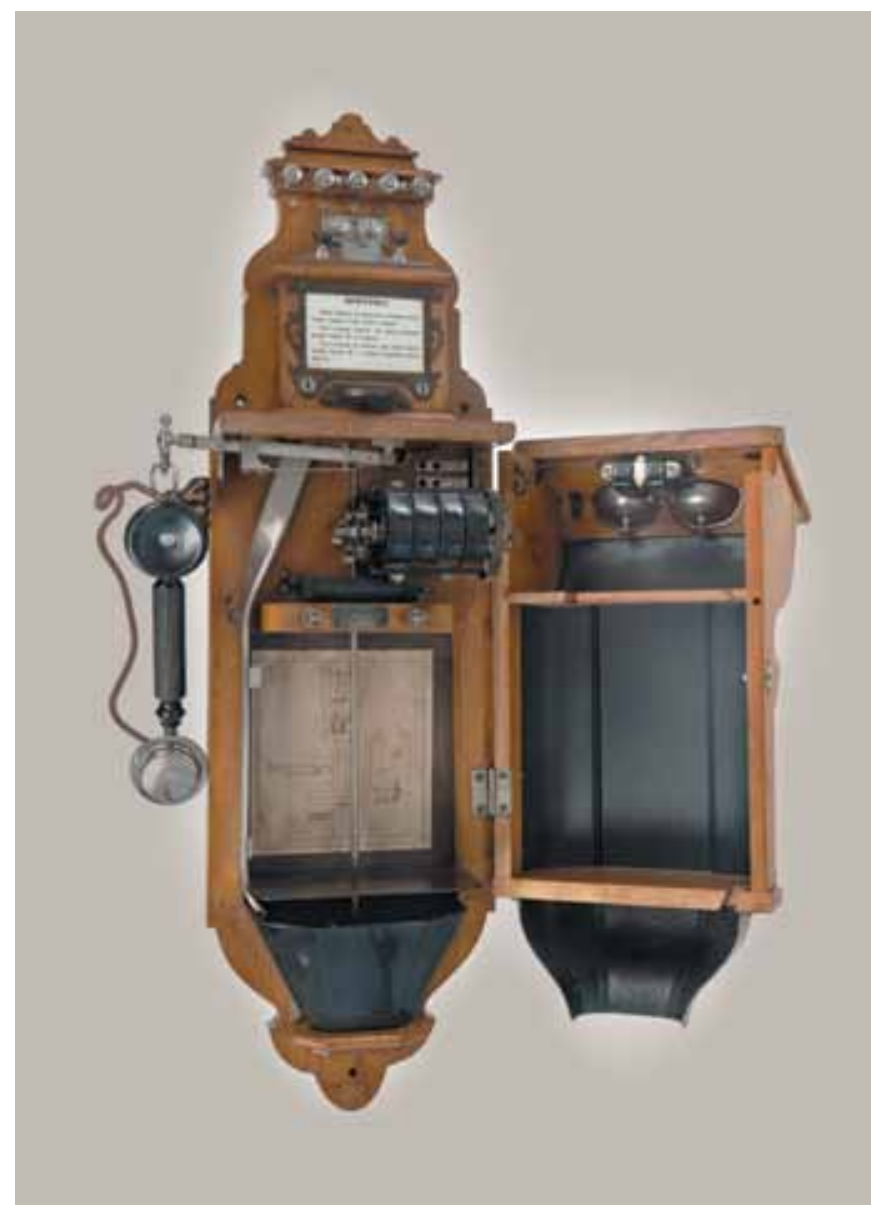

Рис.4. Телефон-автомат. Калужский телефоннотелеграфный завод. 1926 год. Из фондов ЦМС имени А.С.Попова

1917 года. Их производили завод "Красная Заря" и Калужский завод. Такой таксофон выпуска 1926 года можно увидеть среди экспонатов Центрального музея связи имени А.С.Попова (рис.4).

В конце 1920-х годов началась массовая модернизация телефонных сетей, сопровождавшаяся внедрением автоматических телефонных станций. Эти обстоятельства потребовали новых, более совершенных телефонных аппаратов и стимулировали создание таксофонов иной конструкции, способных работать с АТС. Полностью автоматический таксофон в современном понимании с дисковым номеронабирателем в нашей стране был создан только в начале 1930-х годов. Тогда же шире стал использоваться термин "таксофон", но слова "телефон-автомат" или просто "автомат" до конца 20 века были понятны всем.

За основу взяли разработку немецких конструкторов конца 1920-х годов. В 1932 году был

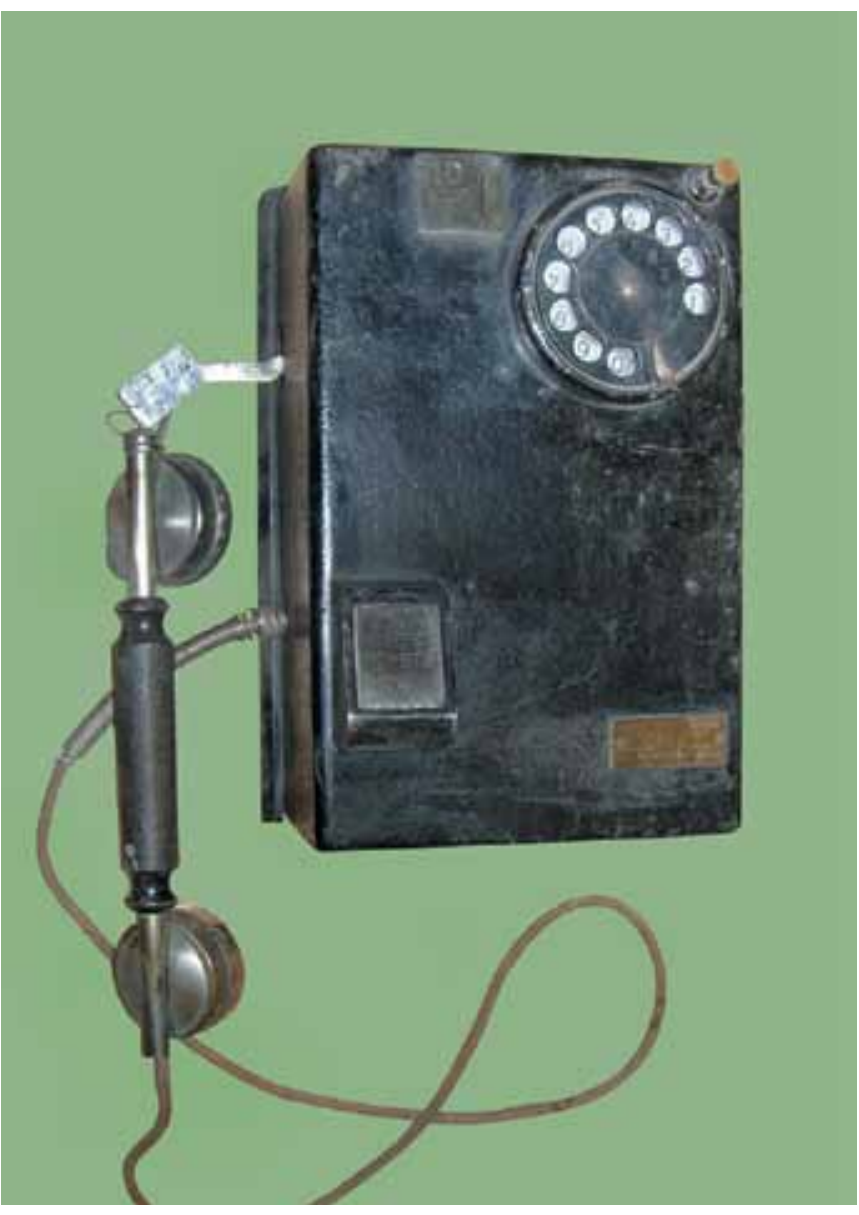

Рис.5. Таксофон системы Комаровского (серии "А"). Калужский завод № 1 Народного комиссариата связи. 1933 год. Из фондов ЦМС имени А.С.Попова

создан первый отечественный таксофон системы Комаровского. Он выпускался под названием таксофон серии "A" (рис.5) Калужским заводом № 1 Народного комиссариата связи, потом заводом "Красная Заря" в Ленинграде. Разговор оплачивался монетой в 10 коп. Имелась ячейка для возврата монеты в случае, если разговор не состоялся.

Позже были разработаны таксофоны серии "Б" и "В". В таксофоне серии "Б" устанавливался дифференциальный трансформатор, уменьшавший явление местного эффекта (прослушивание собственной речи в телефоне).

Таксофоны серии "В", помимо обычного применения, могли использоваться и для двусторонней связи, - на них можно было позвонить. Для этого в аппарат устанавливался звонок и кнопка ручного кассирования монет. Номеронабиратель был снабжен дополнительным блокировочным контактом, позволявшим отличать обычных абонентов от абонентов бесплатных экстренных служб по количеству 
знаков в набранном номере. Таксофоны серии "В" выпускались в двух настенных исполнениях: тип "ВК" со встроенным звонком и тип "ВУ" с клеммами для подключения выносного звонка. Однако телефоны-автоматы этой серии не нашли широкого применения, и в дальнейшем в СССР выпускались таксофоны без функции двусторонней связи.

Строительство АТС, расширение телефонных сетей привели к широкому распространению таксофонов, особенно в крупных городах. В 1937 году в Ленинграде было 1700 таксофонов, в 1938 году в Москве - свыше 2 000. Отечественные таксофоны серий "А", "Б" и "В" прослужили до начала 1950-х годов.

Таксофоны на долгие годы стали для многих единственным средством оперативной связи, их важная роль в человеческой коммуникации нашла отражение в литературе, искусстве, кинематографе, они стали одним из символов культуры 20 века.

\section{ЛИТЕРАТУРА}

1. Автобиографии окончивших курс в Электротехническом Институте. 1889-1904. - СПб: Изд. Электротехнического института, 1908.
2. Барабанов П. Телефонная сеть в Киеве // Почтово-телеграфный журнал. Неоф. отдел. 1893. № 1. С. 82.

3. Губренко И.М., Иоффе И.З., Кучумов Е.В. Телефонные аппараты и таксофоны. История, современное состояние и перспективы развития // Электросвязь. 1976. № 3. С. 28-38.

4. Д.Г. Автоматический кассир для обществен ${ }^{-}$ ных телефонных станций // Электричество. 1891. № 3. С. 41-43.

5. Об устройстве комиссионных павильонов в городе Москве и Санкт-Петербурге инженером И.В.Поповым // РГИА. Ф. 1289. Оп. 8. Д. 694.

6. Обзор выданных привилегий (1901, вып. 1) // Записки императорского Русского Технического общества. 1901. № 6. С. 19.

7. Русское Акционерное общество Л.М.Эриксон и $\mathrm{K}^{\circ}$. Телефонная фабрика и электромеханический завод. [Прейскурант]. - СПб, 1914.

8. Телефоны-автоматы в Ленинграде // Жизнь связи. 1924. № 3. С. 118.

9. Телефонные автоматы в Москве // Жизнь связи. 1924. № 3. С. 166.

\section{КНИГИ ИЗДАТЕЛЬСТВА «ТЕХНОСФЕРА»}

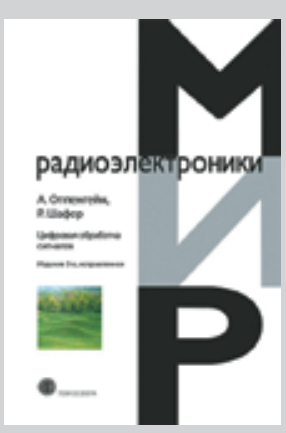

Цена 1300 руб.

\section{ЦИФРОВАЯ} ОБРАБОТКА СИГНАЛОВ А.Оппенгейм, Р.Шафер

\author{
Издание 3-е, исправпенное \\ при поддержке ОАО "РТИ" \\ перевод с англ. под ред. д.э.н., проф. С.Ф.Боева
}

M.: TEXHOСФЕРA,

2019. -1048 C.,

ISBN 978-5-94836-329-5

Предлагаемая вниманию читателя книга - третье переработанное издание всемирно известного классического учебника "Цифровая обработка сигналов", опубликованного в 1975 году. В ее основу лег развернутый курс по дискретной обработке сигналов, преподававшийся в течение ряда лет в Массачусетском технологическом институте.

Учебник посвящен математическим алгоритмам, реализуемым в дискретных системах. В нем опущены сложные доказательства математических утверждений, но все приемы и методы проиллюстрированы многочисленными примерами и задачами.

Книга будет полезна как студентам, осваивающим предмет, так и инженерам-разработчикам и системотехникам. 
TЕХНОСФЕРА

РЕКЛАМНО-ИЗДАТЕЛЬСКИЙ ЦЕНТР

\section{0\% ГАРАНТИЯ ПОЛУЧЕНИЯ ВСЕХ НОМЕРОВ}

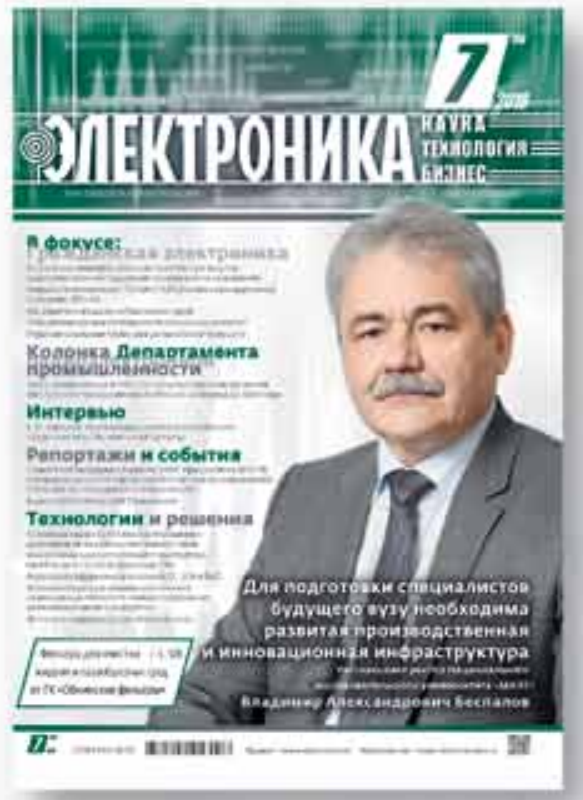

Стоимость 2200 р, за номер

Периодичность: 10 номеров в год

www.electronics.ru

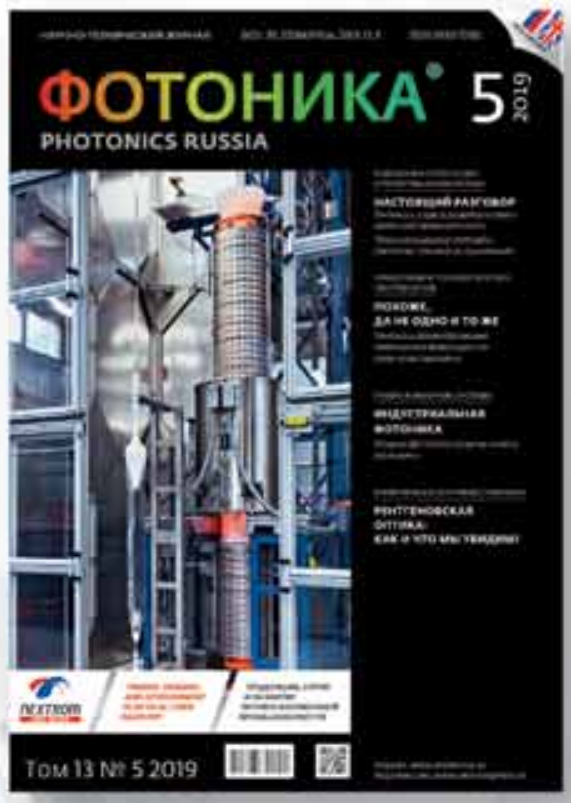

Стоимость 1430 p. за номер

Периодичность; 8 номеров в год www.photonics.su

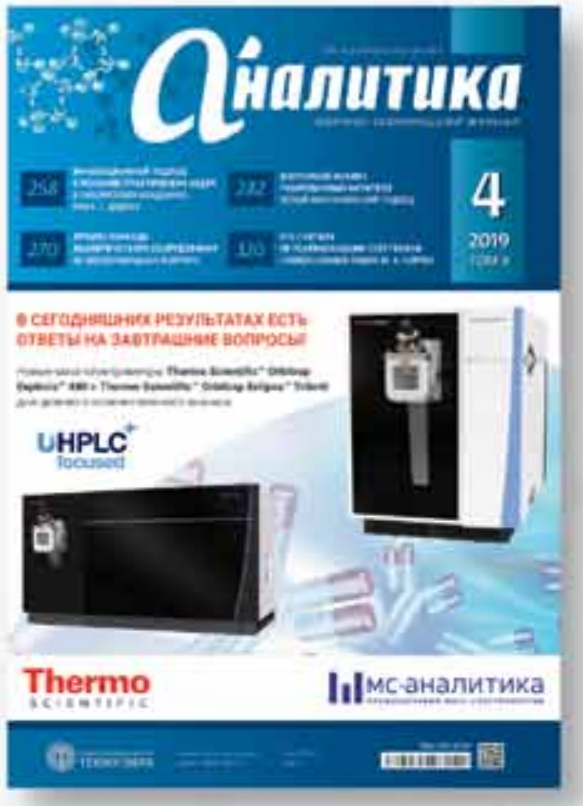

Стоимость 1430 р. за номер

Периодичность: 6 номеров в год www.j-analytics.ru

\section{ПОДПИСКА НА ХУРНАЛЬ}

\section{www.technosphera.ru}

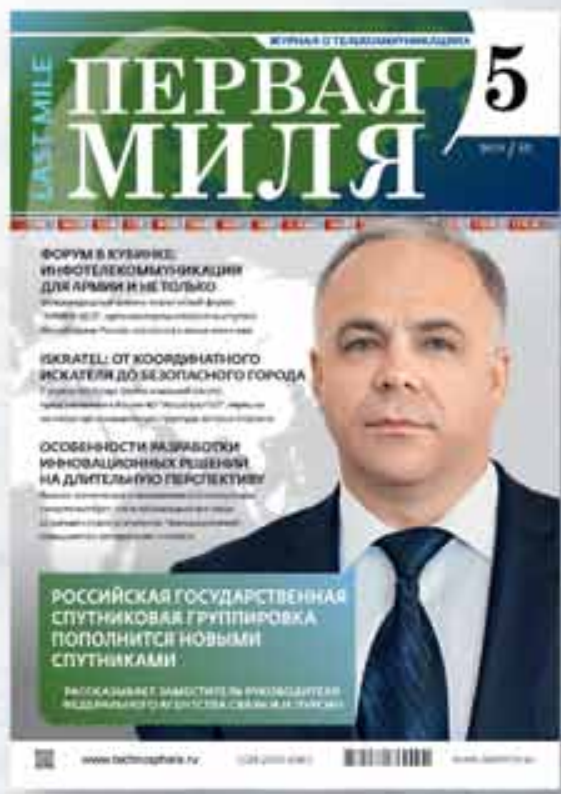

Стоимость 1056 р. за номер

Периодичность: 8 номеров в год www.lastmile.su

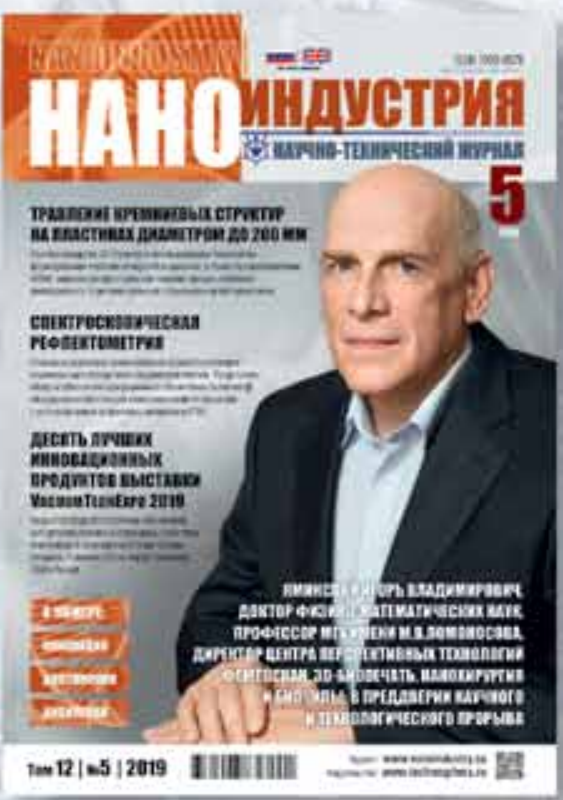

Стоимость 1287 p. за номер

Периодичность: 8 номеров в год

www.nanoindustry.su

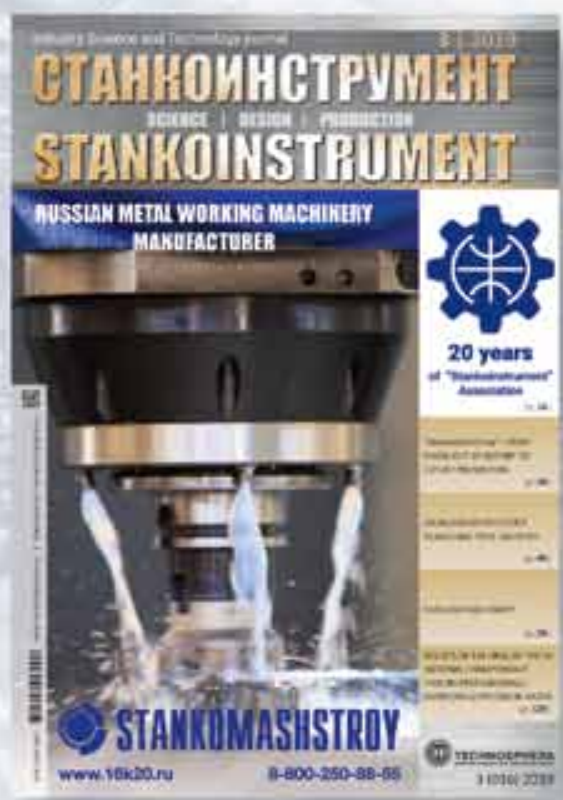

Стоимость 1716 р. за номер

Периодичность: 4 номера в год www.stankoinstrument.su 